\title{
ANALYSIS OF THE INFORMATION TECHNOLOGY USE IN SMALL ENTREPRENEURSHIP IN THE HOSPITALITY INDUSTRY
}

\author{
Dalija Kuvačić 88 \\ Vlasta Roška ${ }^{89}$ \\ Tajana Obradovićc0
}

https://doi.org/10.31410/itema.2018.228

\begin{abstract}
Technology and information systems themselves have no value without their application in business and the creation of tangible benefits and returns on entrepreneurial investment. The introduction of information technology enables faster action and observation of market demands, i.e. guests, and reduction of administrative work and filtering of high quality information that contribute to effective and efficient business. The strategic significance of information technology stems from the ability of information technology to better process and sort data into those essential and less important, leading to up-to-date information that results in fulfillment of the desire of guests. Using modern information technology, entrepreneurs in the hospitality industry can gain competitive advantage.

We introduced the results of the empirical research on target population of corporations and physical persons involved in the hospitality industry in the Republic of Croatia. A multi-stage stratified proportional sample at the 5\% statistical mass level was used only from those entrepreneurs who had less than a hundred employees. 311 respondents were covered, 100 of which are hotel and other type of accommodation owners together with 211 restaurant owners and owners of other type of food catering facilities. The results of our empirical research have undoubtedly demonstrated that small business owners in the hospitality industry are well aware of the advantages of using modern information technology and are supplying adequate IT equipment but are not using the advanced internet business opportunities.
\end{abstract}

Keywords: Information technology, small entrepreneurship in hospitality industry, competitiveness

\section{INTRODUCTION}

\subsection{Subject and methodology of research}

$\mathrm{T}$ The special empirical research was carried out on the target population (statistical mass) of all legal and natural persons in the hospitality business in the Republic of Croatia, according to the National Classification of Activities, i.e. entrepreneurs-owners of these facilities who, at the same time as managers (or elsewhere), are constantly working in their businesses. It was decided that, for research purposes, a more multiphase, stratified and proportional sample at the level of $5 \%$ of the statistical mass, i.e. the population of all hospitality entrepreneurs in the Republic of Croatia, is used only for those with fewer than 100 employees in their permanent employment. There were 311 respondents in the sample, of which 100

\footnotetext{
${ }^{88}$ Zagreb University of Applied Sciences, Vrbik 8, Zagreb, Croatia

${ }^{89}$ University North, Trg dr. Žarka Dolinara 1, Koprivnica, Croatia

${ }^{90}$ Funditus d.o.o., Hanuševa 2, Zagreb, Croatia
} 
owners of hotels and other accommodation facilities, and 211 owners of restaurants and other food preparation and service facilities.

The survey was conducted by e-mail, mail and personal interview with a planned number of 311 respondents, although there were 456 abstinents, i.e. those who refused the survey or did not return the submitted questionnaires. Data for the sample were collected from the primary sources (several reports and press releases of the Central Bureau of Statistics) and from different secondary sources, on the basis of data from the Internet and records in the databases of the following chambers and associations: Croatian Chamber of Trades and Crafts Zagreb and its 20 county subsidiaries, Croatian Hotel Association and Caterers Association, Association of Croatian Campers, Association of Caterers of the City of Zagreb, Croatian Association of Hotels and Restaurants, Association of Caterers and Croatian Barmen.[1]

\subsection{The starting hypothesis}

At the beginning of this empirical research, a starting hypothesis was introduced, which says: Small business owners in the hospitality industry recognize the benefits of using modern information technology and acquire a good piece of IT equipment but are using the advanced internet business opportunities in the hospitality industry insufficiently. [2]

\section{THE IMPORTANCE OF THE INFORMATION TECHNOLOGY IN TOURISM AND HOSPITALITY INDUSTRY}

Nearly half of the reservations in Croatia are made virtually, and the internet and the social network have repressed the traditional sources of tourist destinations. Variable economic conditions, changes in consumer behavior and the development of new technologies will cause new markets to emerge. Due to the increasing amount of investment in information technology, the ways in which companies are investing and using this technology are becoming increasingly important. The ability to successfully manage information technology is slowly becoming one of the major strategic benefits of many companies. Information technology for tourism is a tool that connects all parts of the tourism industry. They allow adding value to a product or service with the connectivity of the tourist subject and its surroundings. These technologies in the tourism industry are developing due to globalization, rapid development of technology, and especially the Internet. [3]

In the segment of e-business in tourism and hospitality, there are user-created content, online communities, destination management systems, mobile ICT technology implementation, hotel electronic distribution, and tourism websites. Each of these parts, apart from each other, can function in symbiosis with other parts because they are technologically dependent on each other. In accordance with the constant development of the Internet, along with its growing role in the world, tourism is also using WEB 2.0 and its services such as user-created content. As the name itself says, user created content has been created by the users, i.e. tourists for other tourists in the form of written texts, shared images, or video works. Important links can be made to TripAdvisor.com and Booking.com's guest ratings. In addition to that, hotels have recently allowed on their own websites users to provide feedback about hotel services they have used. This way, hoteliers can influence improvement of their services even though they control the information that will be displayed on their web pages. Information and communication technologies enable tourists to travel easily and choose a suitable hotel or accommodation based on user-created content. [4] 
Garbin Praničević, Pivčević and Garača explored the development of information systems in large hotel companies in the Republic of Croatia. The results of the research have shown that the development of information systems can be observed according to the development of their components. It is shown that the observed hotels are best suited to group into two clusters according to the corresponding levels of development. These clusters correspond to the highest and middle levels of development. The conclusion is that large hotel companies in Croatia have recognized the importance of information systems and the need to invest in them, but investment in information systems has not been followed by adequate investment in human resources, especially in hotels that have developed information systems.[5] According to M. Porter, information technology is a prerequisite for the company's advancement and competitiveness, represented by brands and innovations, which focus on the needs and desires of consumers and the implementation of technological solutions to meet these needs.[6]

\section{RESULTS OF EMPIRICAL RESEARCH}

As a part of empirical research, the reasons, why respondents, small entrepreneurs in the hospitality industry and their employees use the Internet, have been explored. The results are presented in Table 1. from which it is apparent that the arithmetic mean (in a scale of 7 degrees of importance for each of the 10 offered reasons) ranges from a maximum of 5,38 (send and receive emails to customers, suppliers, owners and similar) to at least 3,65 (communication using chat, forums, etc.).

Table 1: The reason for using the internet in the business of the respondent

\begin{tabular}{|l|c|c|c|}
\hline OFFERED REASONS (alphabetically) & $\begin{array}{c}\text { ARITHMETIC } \\
\text { MEAN }\end{array}$ & $\begin{array}{c}\text { STANDARD } \\
\text { DEVIATION }\end{array}$ & $\begin{array}{c}\text { ASYMMETRY } \\
\text { COEFFICIENT }\end{array}$ \\
\hline $\begin{array}{l}\text { Reading of information (news) from } \\
\text { daily and weekly newspapers }\end{array}$ & 4,56 & 2,16 & $-0,43$ \\
\hline $\begin{array}{l}\text { Communication using chats, forums } \\
\text { and the like }\end{array}$ & 3,65 & 2,17 & 0,16 \\
\hline $\begin{array}{l}\text { Searching databases in search of new } \\
\text { knowledge }\end{array}$ & 4,64 & 1,97 & $-0,43$ \\
\hline $\begin{array}{l}\text { Search knowledge in order to make } \\
\text { good decisions }\end{array}$ & 4,70 & 1,96 & $-0,49$ \\
\hline $\begin{array}{l}\text { Collecting information for our } \\
\text { commercial data bank }\end{array}$ & 4,20 & 2,08 & $-0,16$ \\
\hline $\begin{array}{l}\text { Collection of information to solve } \\
\text { business problems }\end{array}$ & 4,81 & 1,95 & $-0,65$ \\
\hline $\begin{array}{l}\text { Collecting market information from our } \\
\text { industry }\end{array}$ & 5,10 & 1,93 & $-0,85$ \\
\hline $\begin{array}{l}\text { Sending and receiving e-mail } \\
\text { (customers, suppliers, owners, etc.) }\end{array}$ & 5,38 & 2,03 & $-1,07$ \\
\hline $\begin{array}{l}\text { Searching for information related to } \\
\text { private life }\end{array}$ & 3,95 & 2,17 & 0,00 \\
\hline $\begin{array}{l}\text { Finding interesting information from } \\
\text { everyday life }\end{array}$ & 4,38 & 1,97 & $-0,22$ \\
\hline VARIANCE ANALYSIS: $p=0,0000$ & & & \\
\hline
\end{tabular}

Based on the data presented, it can be concluded that respondents and their employees mostly use the internet in accordance with the needs of their everyday business. These findings fully confirmed the initial hypothesis. 
As part of the empirical research, an attempt was made to find out the criteria under which the respondents purchase computer equipment. Results are presented in Table 2, from which it is apparent that the arithmetical mean (on a scale of 7 degrees of importance for each of the 9 criteria offered) is in the range of at most 5,22 (efficiency and effectiveness of the information system) to at least 3,54 (most companies have the equipment, so we purchased it as well).

Table 2: Set of criteria of the IT equipment procurement among the respondents

\begin{tabular}{|l|c|c|c|}
\hline \multicolumn{1}{|c|}{ OFFERED CRITERIA (alphabetically): } & $\begin{array}{c}\text { ARITHMETIC } \\
\text { MEAN }\end{array}$ & $\begin{array}{c}\text { STANDARD } \\
\text { DEVIATION }\end{array}$ & $\begin{array}{c}\text { ASYMMETRY } \\
\text { COEFFICIENT }\end{array}$ \\
\hline $\begin{array}{l}\text { The effectiveness and efficiency of the } \\
\text { information system }\end{array}$ & 5,22 & 1,88 & $-0,88$ \\
\hline $\begin{array}{l}\text { Cost-effective investment in the } \\
\text { information system }\end{array}$ & 4,96 & 1,82 & $-0,73$ \\
\hline Compatibility with existing IT equipment & 4,89 & 1,87 & $-0,73$ \\
\hline $\begin{array}{l}\text { Complementarity with existing IT } \\
\text { equipment }\end{array}$ & 4,72 & 1,91 & $-0,64$ \\
\hline $\begin{array}{l}\text { Quality of information services } \\
\text { systems or parts }\end{array}$ & 5,13 & 1,72 & $-0,83$ \\
\hline $\begin{array}{l}\text { The risk of key automated business } \\
\text { processes }\end{array}$ & 4,46 & 1,77 & $-0,47$ \\
\hline $\begin{array}{l}\text { Security, reliability and protection of } \\
\text { information system }\end{array}$ & 5,20 & 1,77 & $-0,89$ \\
\hline Compatibility of business with IT plans & 4,68 & 1,84 & $-0,62$ \\
\hline $\begin{array}{l}\text { Most companies have the equipment, so } \\
\text { we purchased it, too }\end{array}$ & 3,54 & 2,05 & 0,13 \\
\hline VARIANCE ANALYSIS: $p=0,0000$ & & & \\
\hline
\end{tabular}

Based on the data presented, it can be concluded that respondents, small business owners, use a relatively good set of criteria based on which they purchase IT equipment with little underestimation of some criteria, such as cost-effectiveness of information system investment, compatibility and complementarity with existing IT equipment. These findings were partially confirmed by the initial hypothesis.

As part of the empirical research, an attempt was made to find out the opinion of our respondents about all the benefits of their business to modern information technology. Results are presented in Table 3, from which it is evident that the arithmetic mean (on a scale of 7 degrees of importance for each of the 10 advantages offered) is in the range of not more than 5,76 (more opportunities to communicate with suppliers and customers) to at least 4,91 (greater visualization capabilities and permanent education).

Table 3: Advantages for respondents through modern information technology

\begin{tabular}{|l|c|c|c|}
\hline \multicolumn{1}{|c|}{$\begin{array}{c}\text { OFFERED ADVANTAGES } \\
\text { (alphabetically) }\end{array}$} & $\begin{array}{c}\text { ARITHMETIC } \\
\text { MEAN }\end{array}$ & $\begin{array}{c}\text { STANDARD } \\
\text { DEVIATION }\end{array}$ & $\begin{array}{c}\text { ASYMMETRY } \\
\text { COEFFICIENT }\end{array}$ \\
\hline Quick time and space (place) bridging & 5,32 & 1,63 & $-1,02$ \\
\hline $\begin{array}{l}\text { Options for effective presentation of new } \\
\text { products and services }\end{array}$ & 5,21 & 1,74 & $-0,84$ \\
\hline $\begin{array}{l}\text { The development of new forms of } \\
\text { business information literacy }\end{array}$ & 5,00 & 1,75 & $-0,68$ \\
\hline $\begin{array}{l}\text { Greater promptness of business activities } \\
\text { and the performance of tasks }\end{array}$ & 5,46 & 1,56 & $-1,05$ \\
\hline $\begin{array}{l}\text { Greater autonomy in business decision } \\
\text { making }\end{array}$ & 5,14 & 1,77 & $-0,90$ \\
\hline
\end{tabular}




\begin{tabular}{|l|c|c|c|}
\hline $\begin{array}{l}\text { Greater opportunities to communicate } \\
\text { with target markets }\end{array}$ & 5,46 & 1,64 & $-1,13$ \\
\hline $\begin{array}{l}\text { Greater opportunities to communicate } \\
\text { with suppliers and customers }\end{array}$ & 5,76 & 1,46 & $-1,37$ \\
\hline $\begin{array}{l}\text { Greater opportunities to adapt to } \\
\text { consumers' needs }\end{array}$ & 5,50 & 1,58 & $-1,06$ \\
\hline $\begin{array}{l}\text { Greater capabilities of visualization } \\
\text { and permanent education }\end{array}$ & 4,91 & 1,76 & $-0,69$ \\
\hline $\begin{array}{l}\text { Larger and faster flow and exchange of } \\
\text { business information and documentation }\end{array}$ & 5,68 & 1,53 & $-1,23$ \\
\hline VARIANCE ANALYSIS: $p=0,0000$ & &
\end{tabular}

Based on the data presented, it can be concluded that respondents, small business owners in the hospitality industry, have well recognized and ranked the advantages that modern information technology provides for their business, with little underestimation of some advantages, such as increased business activity and performance, greater communication possibilities with target markets and fast bridging of time and space. These findings confirmed the initial hypothesis.

As part of empirical research, the quality of application of information technology in the business of respondents, small entrepreneurs in hospitality was examined. The results are presented in Table 4. In a separate column in the table, the respondents' replies were ranked to provide a better insight into the results. The variance analysis $(p=0.0000)$ shows that there is a statistically significant variability among 10 offered aspects of IT application in business.

Table 4: Some aspects of IT equipment application in business

\begin{tabular}{|l|c|c|c|}
\hline \multicolumn{1}{|c|}{ OFFERED QUESTIONS: } & YES & RANK & NO \\
\hline $\begin{array}{l}\text { 1. Does the existing IT infrastructure satisfy all the needs of } \\
\text { your company? }\end{array}$ & $67,65 \%$ & 2 & $32,35 \%$ \\
\hline $\begin{array}{l}\text { 2. Does your company have a connection to the internet and } \\
\text { an e-mail address? }\end{array}$ & $77,21 \%$ & 1 & $22,79 \%$ \\
\hline 3. Does your company have a website? & $32,91 \%$ & 5 & $67,09 \%$ \\
\hline 4. Does your company have a Facebook profile? & $28,25 \%$ & 6 & $71,75 \%$ \\
\hline 5. Does your company have Intranet? & $15,40 \%$ & 7 & $84,60 \%$ \\
\hline $\begin{array}{l}\text { 6. Do you exchange data with suppliers and distributors } \\
\text { electronically? }\end{array}$ & $48,45 \%$ & 3 & $51,55 \%$ \\
\hline $\begin{array}{l}\text { 7. Do you do transactions with suppliers and customers } \\
\text { electronically? }\end{array}$ & $43,32 \%$ & 4 & $56,68 \%$ \\
\hline $\begin{array}{l}\text { 8. Does your company offer the possibility of booking via } \\
\text { e-commerce (internet shops)? }\end{array}$ & $14,13 \%$ & 9 & $85,87 \%$ \\
\hline $\begin{array}{l}\text { 9. Can employees do business from home } \\
\text { by telecommuting (teleworking)? }\end{array}$ & $10,09 \%$ & 10 & $89,91 \%$ \\
\hline $\begin{array}{l}\text { 10. Does your company invest in special IT training for } \\
\text { employees? }\end{array}$ & $14,34 \%$ & 8 & $85,66 \%$ \\
\hline VARIANCE ANALYSIS: $p=0,0000$ & & & \\
\hline
\end{tabular}

Based on the data presented, it can be concluded that the basic IT infrastructure and operations, such as the internet, e-mail and electronic communication with suppliers and distributors, prevail in the business of respondents, but unfortunately they miss a more advanced and in modern business activities necessary means of using IT equipment, such as e-commerce booking (internet commerce) and home-based business (teleworking), which can somewhat be justified by the fact that the survey was conducted among small business owners. These findings fully confirm the initial hypothesis, which states: Small business owners in the hospitality 
industry are well aware of the advantages of using modern information technology and acquire adequate IT equipment but are insufficiently using the advanced internet business opportunities in the hospitality industry. [7]

This empirical research has limitations since it was implemented before the introduction of fiscalization in the Republic of Croatia. Fiscalization is an obligation to issue invoices through electronic payment systems directly related to the Tax Administration. The Law on Fiscalization introduced a more complete control of the Tax Administration on the turnover of entrepreneurs who supply goods and services in cash, with the aim of better tax collection, the suppression of gray economy and reduction of tax evasion. Institutions, associations and other legal entities that are not taxable income taxpayers do not have a fiscal obligation even though some deliveries are billed in cash. [8] Since now all small business owners in the hospitality industry have to be connected to the Internet to issue fiscalized accounts, the results of this empirical research today would certainly be different. This opens up the possibility to authors for future research.

\section{CONCLUSION}

From all presented results of empirical research, it can be concluded that the small business owners in the hospitality industry have well recognized and ranked the advantages that contemporary information technology provides for their business, with a little underestimation of some benefits, such as greater promptness of business activities and performance, greater communication possibilities with target markets and rapid bridging of time and space (places). They have identified and ranked the offered sources of competitive advantage based on the use of information technology, with the neglect of knowledge transfer using the intranet and the internet, the inadequate level of continuous professional training of employees, and the organization of training and other forms of employee learning that are very important for creating competitive advantages of hospitality companies.

Competitive advantages indicate a set of determinants of hospitality of company's offer that enables it to compete more effectively, i.e. better market position than other competitors in the target market, and greater opportunities for conquering new markets. Competitive advantages are most often achieved by innovating, modifying and differentiating products or services by adjusting their features, assortments and (after) sales services, by adjusting and differentiating prices through market segmentation, distribution, promotion and the like. Significant role in achieving the competitive advantage of small business owners in the hospitality industry in Croatia must have the use of advanced information technology in their day-to-day business. Entrepreneurs who have recognized the benefits of electronic business will surely gain a better competitive position on the market and greater recognition among their customers.

\section{REFERENCES}

[1], [2], [7] Kuvačić, D. (2012) Utjecaj novih znanja na konkurentnost malog poduzetništva u ugostiteljstvu (PhD Thesis), Faculty of Management in Tourism and Hospitality, University of Rijeka, Opatija

[3] Garbin Praničević, D. (2013) Informacijski sustavi u turizmu i ugostiteljstvu, Faculty of Economics, University of Split, Split, pp. 15.

[4] Radić, T. (2013) Suvremena tehnološka rješenja kao potpora hotelskom poslovanju na području Splitsko-dalmatinske županije, available at: http://elib.efst.hr/2013/2111870.pdf. 
[5] Garbin, Praničević, D., Pivčević, S., Garača, Ž. (2010) Razvijenost informacijskih sustava velikih hotelskih poduzeća u Hrvatskoj, Acta Turistica Nova, Zagreb, 4 (2), pp. 15.

[6] Porter, M. E. (2008) Konkurentska prednost - postizanje i održavanje vrhunskog poslovanja, Masmedia, Zagreb, pp. 20.

[8] http://savjeti.novac.net/blogovi/sto-je-fiskalizacija-obveznici-fiskalizacije/ (10.10.2018.) 